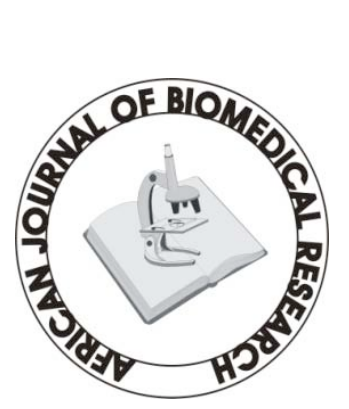

Full-text available at http://www.ajbrui.com http://www.bioline.br/md http://www.ajol.com
Received:

January 2008

Accepted (Revised):

June 2008

Published

Septemeber 2008
Full Length Research Article

\section{Effects of Methanolic Root Extract of Ledebouria ovaltifolia (Hyacithaneae) on Isolated Smooth Muscle Preparation in Rats}

\author{
Peter I. Aziba
}

Swaziland Institute for Research in Medicine, Medicinal and Indigenous Food Plants (SIRMIP)

University of Swaziland, Swaziland, Southern Africa

\section{ABSTRACT}

This study investigated the receptor effects of methanolic root extract of ledebouria ovaltifolia on Acetylcholine and Potassium $\left(\mathrm{K}^{+}\right)$induced contractions in Rat stomach strip (RSS), Adrenaline and $\mathrm{K}^{+}$(induce contractions) in rat vas deferens (RVD), and carbachol and $\mathrm{K}^{+}$induced contractions in rat uterus (RUT). Effects of the root extract $(1.27 \mathrm{mg} / \mathrm{mL})$ on acetylcholine $\left(6.8 \times 10^{-9}\right.$ to $\left.10.4 \times 10^{-8} \mathrm{M}\right)$ adrenaline $2 \times 10^{-7} \mathrm{M}$, carbachol $\left(2 \times 10^{-}\right.$ ${ }^{8} \mathrm{M}-1.6 \times 10^{-7} \mathrm{M}$ ), and $\mathrm{K}^{+}$contractions were non competitive. Results of muscle contractility in zero-Ca ${ }^{2+}$ containing $0.5 \mathrm{mM}$ EGTA varies in these tissues in this order RSS $>$ RVD $>$ RUT. It is concluded in this study, the inhibitory effect of the extract was non specific on muscarinic, adreneceptors nor depolarised membrane site. The effect of the extract was more marked on potassium $\left(\mathrm{K}^{+}\right)$ than receptor mediated contractions.

(Afr. J. Biomed. Res. 11: 232 - 327)

Key Words; ledebouria Ovaltifolia, Extract, methanolic, smooth muscle contractions, rodents

Corresponding author: PeterAziba@yahoo.com; Tel: 268 6235196; Fax: 5185276

Abstracted by:

African Index Medicus (WHO), CAB Abstracts, Index Copernicus, Global Health Abstracts, Asian Science Index, Index

Veterinarius, Bioline International, African Journals online 


\section{INTRODUCTION}

The aim of this study was to further investigate the methanolic root extract of Ledebouria Ovaltifolia whose pharmacological properties are little known, scientifically in muscle contractions. The effects of the extract was examined on different tissues isolated from different anatomical sites of the rat under various experimental conditions. The inhibitory actions of the aerial part of the extract had been reported (Aziba 2007). This investigation was studied on isolated rat stomach strip (RSS), Rat Van Deferens (RVD) and rat uterus which has highly regular spontaneous contractions that are inhibited by many endogenous mediators such as catecholamine Lum et at (1966) and adenosine (Ally and Nakatsu 1976).

\section{MATERIALS AND METHODS}

Plant Collection \& Extraction: The root of ledebouria Ovaltifolia (hyacithaceae) was collected from fields in Malkerns Research Station in Swaziland in March 2006, the sample was authenticated by the curator Mr Dlamini and a voucher specimen no. (ADW 2243T) was deposited for keeps in the herbarium. The root $(350 \mathrm{~g})$ were pound using piston and mortar then blended using a blender (moulinex), the ground extract was soaked in Dichloromethane and methanol (ratio 3:1) and soxhlet extracted. The brown filtrate was collected and preserved in the refrigerator below $-200^{\circ} \mathrm{C}$.

Phytochemical Analysis: Photochemistry of the methanolic extract was carried out using the method of (Harbour 1998). The result indicated the presence of steroids, saponin, tannin and anthraquinone.

Animals: Healthy male and female albino rats $(250-350 \mathrm{~g})$ were used in these studies. All animals were raised at room temperature with natural light dark circle and maintained at standard rodent pellets and had access to water.

Drug Used:Acetylcholine chloride (sigma) andrenaline (Fluka) carbachol, (Aldrich), Potassium chloride (Aldrich).

\section{Experimental Procedures:-}

Rat Vas Deferens (RVD) preparation: The epididymal end of the rat Vas Deferens was mounted with resting tension $0.5 \mathrm{~g}$ in an organ bath containing Tyrode solution in the following composition in $\mathrm{mM} / \mathrm{L} \mathrm{NaCl}$ (137), $\mathrm{KCl}(-2.8)$, $\mathrm{CaCl}_{2} \cdot 2 \mathrm{H}_{2} \mathrm{O} .(1.8), \quad \mathrm{MgCl}_{2} \cdot 6 \mathrm{H}_{2} \mathrm{O}$.(1.3), $\mathrm{NaHCO}_{3}$ (11) and glucose (2) and allowed to equilibrate for $60 \mathrm{~min}$ and the solution in the bath was continuously bubbled with $95 \%$ or $5 \% \mathrm{CO}_{2}$ with temperature maintained at $37^{\circ} \mathrm{C}$, contractions were monitored through isometric force transducer ugo Basile and recorded on a 2-channel dynamometer (Gemini). Dose effect relationship to $\mathrm{K}^{+}$and adrenaline were recorded, a sub maximal doses of $\mathrm{K}^{+}\left(60 \mathrm{mM}\right.$ and adrenaline $\left.2 \times 10^{-7} \mathrm{M}\right)$ were exposed to physiological solution containing $1.27 \mathrm{mg} / \mathrm{ml}$ of the extract.

\section{Rat Stomach Strip (RSS) Preparations:} Animals were killed by fracture. An incision was made to open the abdomen and the rat stomach strip (RSS) was isolated according to the method described by Vane (1957). Muscle contractions monitored as previously described. (Tyrode solution composition as previously described in Rat vas Deferens.

Rat Uterus Preparation (RUT): Mature female albino rats were killed by cutting one of the common carotid arteries, the uterine horns were rapidly excised and carefully cleaned of surrounding connective tissues and opened along the mesenteric border the myometrial tissue was cut into longitudinal strip and were mounted vertically in a $15 \mathrm{ml}$ organ bath containing De Jallon solution containing composition in $(\mathrm{mM}$ $\mathrm{Nacl},(153), \mathrm{KCl},(56)$, glucose (61.2), $\mathrm{NaHCO}_{3}$ ,(59) gassed with 95\% oxygen and 5\% carbon dioxide and $37^{\circ} \mathrm{C}(\mathrm{pH} 7.4)$ : The tissue $1 \mathrm{~g}$ tension was allowed to equilibrate for $1 \mathrm{hr}$ before addition of drug. The tissue tension was recorded as previously described. In some experiments $\mathrm{Ca}^{2+}$ was omitted in the physiological solution. 


\section{RESULTS}

Effect of root extract ledebouria ovaltifolia $1.27 \mathrm{mg} / \mathrm{ml}$ on Ach-induced contraction in Rat Stomach Strip

Dose effect relationship was established using acetylcholine (ach) concentration ranging from 6.6 $\mathrm{x} 10^{-9} \mathrm{M}$ to $10.4>10^{-8} \mathrm{M}$ ) after which the strip was equilibrated in the methanolic extract $(1.27 \mathrm{mg} / \mathrm{kg})$ for 3 minutes. The tissue was again stimulated with some doses of Ach.
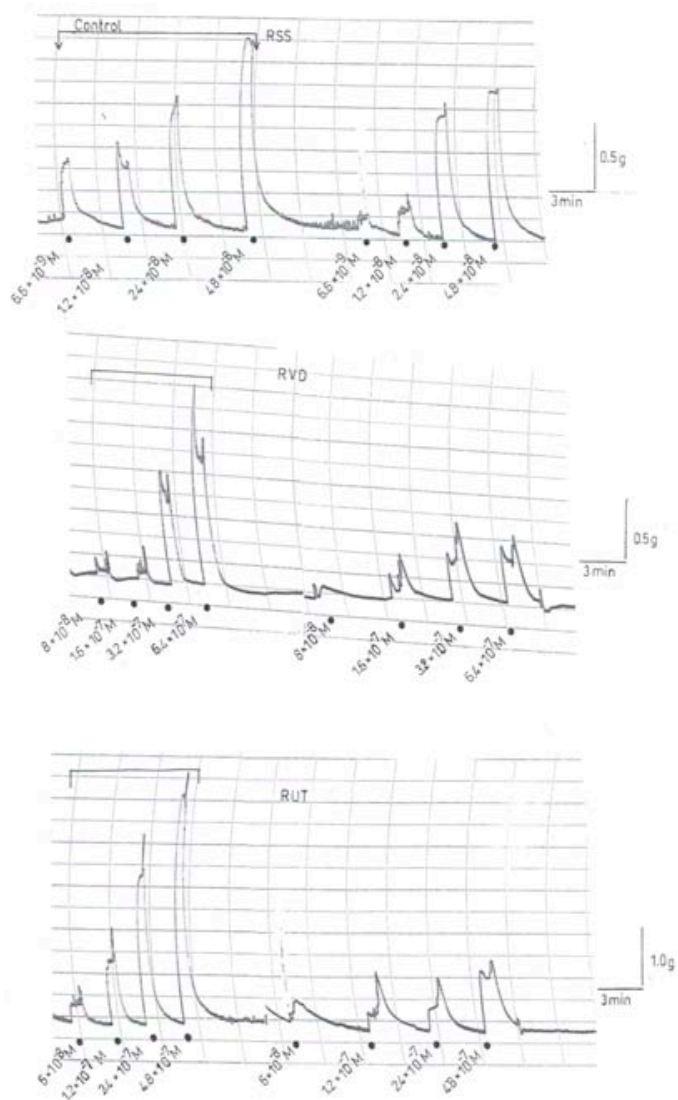

Figure 1: (a)Tracings showing the inhibitory effects of extract (L.Ovaltifolia) $1.27 \mathrm{mg} / \mathrm{ml}$ on Ach-induced contractions of RSS. Control responses to ach $\left(6.6 \times 10^{-4} \mathrm{M}\right.$ to $\left.10.2 \times 10^{-8} \mathrm{M}\right)$ extract inhibited responses $(\uparrow)$ vertical bar 0.5 and horizontal time interval. (b)Tracings show the inhibitory effect of extract (L. Ovaltifolia) $1.27 \mathrm{mg} / \mathrm{ml}$ on adrenaline on rat vas deferens. $\mapsto$ Arrow indicate point of extract addition and $(\bullet)$ responses in the presence of extract. Vertical bar $0.5 \mathrm{~g}$ and horizontal time interval. (c) Tracings show the inhibitory effect of extract (L. Ovaltifolia) $1.27 \mathrm{mg} / \mathrm{ml}$ on carbachol-induced contraction in uterine muscle. Arrow $(\ulcorner)$ indicate point of extract addition for tannin. While $(\bullet)$ indicate doses of adrenaline vertical bar $1.0 \mathrm{~g}$ and horizontal bar time interval.
The extract significantly inhibited ach induced contractions in a non competitive manner and maximum contractile heights were depressed similarly this was done for adrenaline $\left(2 \times 10^{-7} \mathrm{M}\right)$ and carbachol $\left(2.0 \times 10^{-8} \mathrm{M}-1.6 \times 10^{-7} \mathrm{M}\right)$ doses in rat vas deferens and rat uterus respectively. Effects of methanol extract Ledebouria Ovaltifolia on adrenalin and $\mathrm{K}^{+}$induced contractions in Rat Vas Deferens shows similar actions (see fig 1a,b and c).

\section{Effect of extract (ledebouria ovaltifolia $1.22 \mathrm{mg} / \mathrm{ml}$ ) in submaximal doses of adrenaline and $\mathrm{K}^{+}$in Rat Vas Deferens}

A dose effect relationship was established with adrenaline and $\mathrm{K}^{+}$in separate experiments, after which the sub maximum dose of adrenaline $\left(2 \times 10^{-}\right.$ $\left.{ }^{7} \mathrm{M}\right)$ was examined in the PSS containing the extract, similarly with $\mathrm{K}^{+}(60 \mathrm{mM})$. The extract inhibited up to $70 \%$ and $65 \%$ contractile heights of Adrenaline, $\mathrm{K}^{+}$contractions respectively (see fig 2). (\% inhibitory effect was calculated from heights of contractions the maximum response before the addition of the extract. This action was more marked in $\mathrm{K}^{+}$than adrenaline (see fig 2).

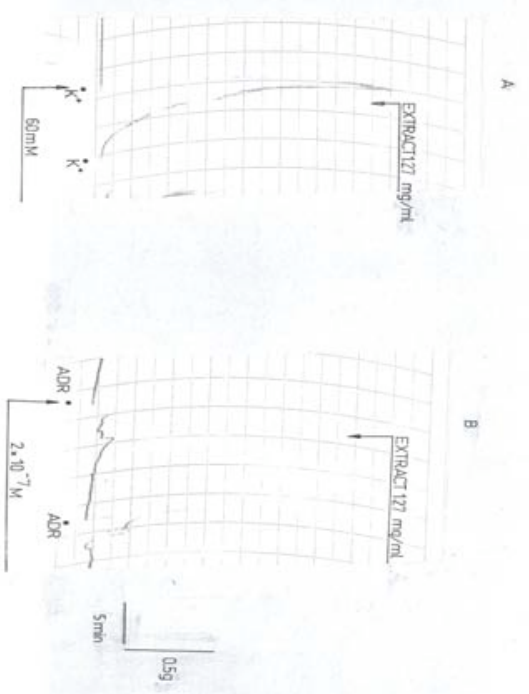

Figure 2

Effect of root extract L.Ovaltifolia $(1.27 \mathrm{mg} / \mathrm{ml})$ on sub maximal doses of $\mathrm{Kcl}(60 \mathrm{mM})$ and Adrenaline $\left(2 \times 15^{-7} \mathrm{M}\right)(\bullet)$ point of addition of drug. Panel $\mathrm{A} \mathrm{K}^{+}$and Panel B Adrenaline vertical bar $0.5 \mathrm{~g}$ and horizontal bar interval $3 \mathrm{~min}$.

Effect of extract (Ledebouria ovaltifolia 


\section{$1.27 \mathrm{mg} / \mathrm{ml}$ ) on spontaneous uterine contractions}

The uterine tissue due to its spontaneous contractions was observed for a period of $1 \mathrm{hr}$ when it was stable and extract was added to the PSS. The extract completely blocked spontaneous contractions, (see fig 3), less that $40 \%$ of spontaneous contractions was restored after washing out the extract from the bathing solution.

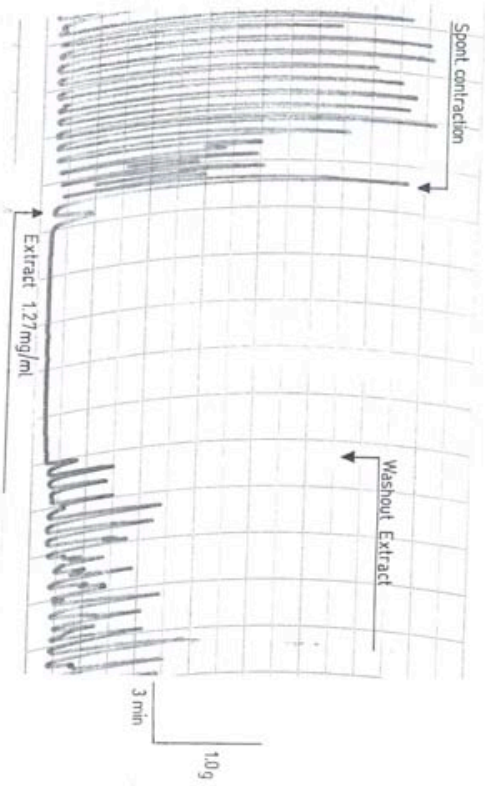

Figure 3

Effects of root extract $l$. ovaltifolia $(1.27 \mathrm{mg} / \mathrm{ml})$ on spontaneous uterine contractions (arrows) point of extract addition ( $\downarrow$ ) ( $\sqsubset$ ) point of washing out the extract. Vertical bar indicate tension $1.0 \mathrm{~g}$ and horizontal time interval.

Effect of free $\mathrm{Ca}^{2+} 0.5$ MEGTA on sub maximal responses of RSS, RVD and RUT

Effects of extra cellular free $\mathrm{Ca}^{2+}$ and $0.5 \mathrm{mM}$ EGTA on contractile RSS, RVD, RUT; was examined after obtaining a dose effect relationship in all the tissues contractions, a sub maximal contractile responses were examined in free $\mathrm{Ca}^{2+}$ containing $0.5 \mathrm{mM}$ EGTA the responses diminished in this order RSS>RVD>RUT; the uterine muscle sustained at contractile effect under this condition (see fig 4).
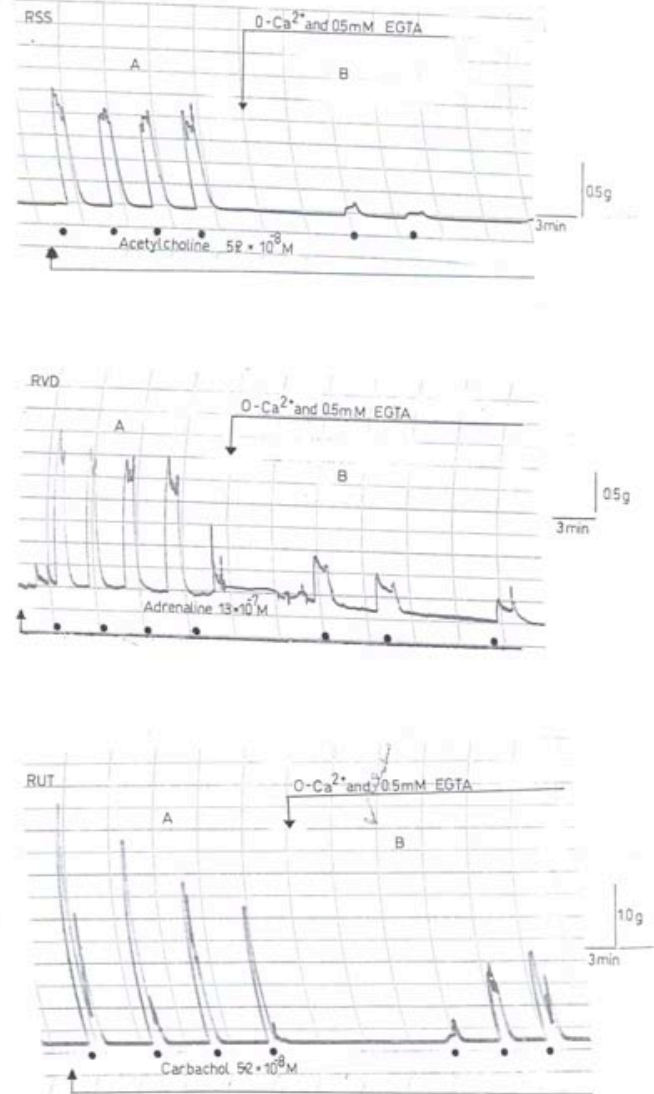

Figure 4

Effect of free $\mathrm{Ca}^{2+}$ containing 0.5mM EGTA on submaximal contractions (RSS $\left.5 . .5 \times 10^{-8} \mathrm{M}\right), \mathrm{RVD}$, Adrenaline $\left(1.3 \times 10^{-}\right.$ $\left.{ }^{7} \mathrm{M}\right)$, and RUT carbachol $\left(5.2 \times 10^{-8} \mathrm{M}\right) . \mathrm{a}=$ Control responses in normal physiological solution. $\mathrm{b}=$ Responses in $\mathrm{O}-\mathrm{Ca}^{2+}$ $0.5 \mathrm{mM}$ EGTA. Vertical bar indicate tension in grames. Horizontal bar indicate time interval

\section{DISCUSSION}

The inhibitory effects of the extract in the muscles studied, (rat vas deferens (RVD), rat stomach strip (RSS) and rat uterus (RUT), from different anatomical sites of the mammalian rodents is consistent with earlier work (Aziba, 2007) in all, the tissues. The extract inhibited contractile effects of acetylcholine carbachol and adrenaline and $\mathrm{K}^{+}$non-competitively, because maximum heights of contractions were depressed, suggesting a non specific action on muscurinic, adrenoceptor, nor depolarised membrane sites. It is well established that excitation contraction coupling in smooth muscle is initiated by a rise in cytosolic 
$\mathrm{Ca}^{2+}$ (Suzuki et al 1990). In this study agents stimulating different ion channel sites were used. Those stimulating receptor operated calcium channel acetylcholine, carbachol and adrenaline, and $\mathrm{K}^{+}$stimulating voltage operated calcium channels. The prototype drugs carbachol acetylcholine and adrenaline open ion channels via receptor operated calcium channel without membrane depolirisation, while $\mathrm{K}^{+}$opens ion channels by depolarising muscle membrane (Grugner et al, 1986). Smooth muscle relaxation or inhibitory by any agent synthetic or non synthetic are mediated by various mechanism such as $\mathrm{K}^{+}$channel opening receptor channel blockade or by receptor antagonism such as antimuscarinic, antihistamimic (Undem, et al) or blockade of adrenoceptors (Bottom, 1979). Contraction of isolated smooth muscle by high $\mathrm{K}^{+}$on the other hand $(60 \mathrm{mM})$ in extracellular fluid is known to depolarise muscle membrane via voltage operated channel; while contraction by $\mathrm{K}^{+}$are directly related to influx of $\mathrm{Ca}^{2+}$ into the cell through $\mathrm{L}$ type channel (Kuriyama, et al,1995). In the present study the result indicated action of the extract was more marked on receptor mediated $\mathrm{K}^{+}$ contractions than mediated responses, which indicate extract may be interacting more with receptor operated calcium channel. This corroborates our earlier findings (Aziba, 2007). The totality of the inhibitory effect of the extract on all muscles contractions in this study indicates the extract interaction with contractile mechanisms in smooth muscles. The non competitive action of the extract on all three muscles used, is indicative of non specific action on muscarinic adrenoceptors or depolarised membrane, because while specificity of actions of prototype drugs atropine and phantolamine will reverse the effect of acetylcholine and adrenaline respectively. The results obtained in free $\mathrm{Ca}^{2+}$ physiological salt solution on the maximal doses of the prototype drugs. The diminished contractility in RSS and RVD would suggest low intracellular $\mathrm{Ca}^{2+}$ holding capacity of these tissues, RSS and RVD under the same experimental condition the rat uterus contraction were sustained which indicated RUT has a better intracellular $\mathrm{Ca}^{2+}$ holding capacity for its contractions. It could be speculated that the intracellular $\mathrm{Ca}^{2+}$ The sustained contraction in uterus is indicative of a strong intracellular $\mathrm{Ca}^{2+}$ might be due to a better sarcoplasnic structure in this muscle compared to RSS or RVD. The methanolic extract on the basis of concentration was more potent that the aqueous extract more than ten fold on molar basis. The methanolic extract possesses antispasmodic action in all muscles used irrespective of its anatomical sites. The phytochemical analysis of the extract indicated the presence of tannin, saponin, flavanoids, glycosides. These constituents are known to be bioactive agents. Overall these results tend to support the various herbal uses of this plant in Swaziland.

\section{ACKNOWLEDGEMENT}

The author wishes to thank the Director of SIRMIP for his support, and Mr Gugu Mavuso for his technical assistance in the animal house. Thanks to Sharon for typing the manuscript.

\section{REFERENCES}

Aziba P.I. (2007): Inhibitory effects of Ledebouria Ovaltifolia (hyacithaceae aqueous root extract on contractile responses of rat vas deferens to $\mathrm{K}$ and adrenaline, pendular movement of isolated rabbit jejunum and acetic acid induced pain in mice Afr. J. of Biomed Res. Vol. 10 89-93

Bolton T.B., (1979): Mechanism of action of transmitter and other substances on smooth muscle Physiol. Rev 59: 607-718.

Gragner S.E., Hollingsworth, M and Weston, A.H. Br. J. Pharmacol, 1986, 87,147.

Kerins D.M. Robertson, R.M. and Robertson D. In Hardman, J.G. (2001): Limbird, L.E. and Gilman Eds. Goodman's The pharmacological Basis Therapeutics, $10^{\text {th }}$ Edn. McGrwoth York, 2001, 843.

Suzuki, H. and Chen, G., (1990): Endothelium derived hyperpolirising factor (EDHF) on endogenous potassium channel opener news in Physiol Sci 5, 212215.

Trease Evans, M.C. (1983): Text book of pharmacology London, Vallerie Tindal pp. 343-383.

Undem, B.J. and Lichtenstein, L.M. (2001): In Hardman J.G. Limbird, L.E. and Gilman Eds, Goodman and Gilman's The pharmacological basis of Therapeutics 10 ${ }^{\text {th }}$ Edn, McGraw-Hill, New York, 2001.

Vane J.R. (1957) - A sensitive method for assay of 5hydroxy-tryphamine Br. J. pharmacol. Exp. Ther 218, 459-464. 
African Journal of Biomedical Research 2008 (Vol. 11) / Aziba

ב 